\title{
Effect of DGAT1, leptin and TG gene polymorphisms on some milk production traits in different dairy cattle breeds in Hungary
}

István Anton', Katalin Kovács', Gabriella Holló², Valéria Farkas³, Ferenc Szabó3, István Egerszegi' ${ }^{1}$ József Rátky ${ }^{1}$, Attila Zsolnai' and Klaus-Peter Brüssow ${ }^{4}$

${ }^{1}$ Research Institute for Animal Breeding and Nutrition Herceghalom, Hungary, ${ }^{2}$ University of Kaposvár, Hungary, ${ }^{3}$ Georgikon Faculty of Agriculture Keszthely, University of Pannonia, Hungary, ${ }^{4}$ Leibniz Institute for Farm Animal Biology (FBN), Dummerstorf, Germany

\begin{abstract}
The objective of this study was to estimate the effect of acylCoA-diacylglycerol-acyltransferase 1 (DGAT1), leptin and thyroglobulin (TG) loci on the milk fat, milk protein and milk yield in Holstein Friesian, Jersey and Hungarian Simmental cows. Leptin and DGAT1 genotypes were determined by qPCR assay, while TG genotypes were identified using the polymerase chain reaction-restriction fragment length polymorphism technique (PCR-RFLP). DGAT1 GC/GC cows had the highest 305-day milk yield values. Difference between AA/AA and GC/GC genotypes was significant $(P<0.05)$. Leptin $C C$ animals produced significantly higher 305-day milk protein percent values $(P<0.05)$ than other genotypes in Hungarian Simmental breed. At TG locus TT cows showed the highest 305-day milk fat percent values, although differences between genotypes proved to be significant $(P<0.05)$ only in Jersey breed.
\end{abstract}

Keywords: dairy cattle, DGAT1, leptin, TG, qPCR, PCR-RFLP, milk yield, milk fat, milk protein

\section{Introduction}

DGAT1 is a microsomal enzyme that catalyses the final step of triglyceride synthesis. A lysine/alanine (K232A) polymorphism in DGAT1 has been shown to affect milk fat content (Grisart et al. 2002). The lysine allele of DGAT1 gene has a positive effect on milk fat content in different cattle breeds (Winter et al. 2002, Strzałkowska et al. 2005). Spelman et al. (2002) investigated the effect of the DGAT1 polymorphism in different dairy breeds and significant differences were demonstrated for milk yield, as well as milk fat and protein content. Highly significant differences were observed for milk fat, milk protein and milk yield in HolsteinFriesian cows (Thaller et al. 2003, Bennewitz et al. 2004). Variable numbers of tandem repeat (VNTR) polymorphisms in the promoter region of the DGAT1 gene also seem to affect milk production traits (Kühn et al. 2004). Gautier et al. (2007) concluded that VNTR polymorphism in Normande and French Holstein breeds was responsible only for a small fraction of the variance of the QTL, while the K232A polymorphism had a large effect on milk production and milk composition. Sanders et al. (2006) reported about a specific allele of the DGAT1 promoter VNTR, which showed significant effects on the lactose content and milk energy content, compared with other alleles. 
Leptin is the hormone product of the obese gene synthesised and secreted predominantly by adipocytes and its expression is regulated by body fatness and energy balance. This protein is supposed to be involved in the regulation of body weight by transmission of a lipostatic signal from adipocytes to the leptin receptor in the hypothalamus resulting in appetite suppression and increased thermogenesis (Zhang et al. 1994, Ji et al. 1998). The leptin gene has been mapped to bovine chromosome 4 (Stone et al. 1996). Polymorphisms in the leptin gene have been associated with milk yield in dairy cattle (Liefers et al. 2002). Animals with TT genotype of the R25C single nucleotide polymorphism in the bovine leptin gene showed increased milk production and milk protein yield compared with CC and CT genotypes, respectively (Buchanan et al. 2003). TT animals of the UASMS2 polymorphism in the bovine leptin promoter region could be associated with the highest marbling score, serum leptin concentration and backfat thickness (Nkrumah et al. 2005).

$T G$ is a glycoprotein precursor of hormones that influence lipid metabolism and is synthesised in the thyroid gland. The effect of a C/T single nucleotide polymorphism (SNP) in the $5^{\prime}$-untranslated region of $T G$ gene has been deduced to affect intramuscular fat content in cattle (Barendse 1999). TG and DGAT1 genes physically mapped to the centromeric region of the bovine chromosome 14 (Coppieters et al. 1998, Winter et al. 2002) and are separated by about 25cM (Moore et al. 2003, Thaller et al. 2003). Many studies mentioned in this chromosomal region a QTL effect on milk fat yield and milk fat percentage in dairy cattle (Khatkar et al. 2004). Based on previous QTL studies in different cattle breeds and on the impact of this gene on fat metabolism, Khatib et al. (2007) investigated the effect of the TG gene on milk production traits. Analysis of 29 sire families showed no significant association between $T G$ variants and milk production traits.

The objective of this study was to estimate the effect of DGAT1, leptin and TG loci on some milk production traits in different dairy cattle breeds in Hungary. Considering that previous results for the possible use of the mentioned polymorphisms in selection to improve milk production traits are rather contradictory, it has been decided to carry out studies in different Hungarian dairy cattle populations with the aim to provide additional data to this particular subject.

\section{Material and methods}

1236 blood samples were collected from Holstein Friesian $(n=415)$, Jersey $(n=340)$ and Hungarian Simmental ( $n=481$ ) cows. Genomic DNA was isolated from whole blood (Zsolnai et al. 2003). Blood samples were stored at $-20^{\circ} \mathrm{C}$ until DNA extraction. Genotyping of the DGAT1 and leptin polymorphisms was performed using a TaqMan allelic discrimination method in a Rotor-Gene RG 3000 Real-Time PCR system (Corbett Research UK Ltd, Cambridge, UK). Primers and labeled oligonucleotide probes were designed based on the leptin sequence (UASMS2, C/T substitution at position 528 according to GenBank acc. no. AB070368): forward, $5^{\prime}-A G G$ TGC CCA GGG ACT CA-3'; reverse, 5'-CAA CAA AGG CCG TGT GAC A-3'; FAM probe, 5'-CAA GCT CTA GAG CCT GTG T-3'; HEX probe, 5'-AAG CTC TAG AGC CTA TGT-3'. PCR cycling conditions were: $95^{\circ} \mathrm{C}$ for $10 \mathrm{~min}$, followed by 40 cycles of $95^{\circ} \mathrm{C}$ for $7 \mathrm{~s}, 55^{\circ} \mathrm{C}$ for $7 \mathrm{~s}$ and $72^{\circ} \mathrm{C}$ for $15 \mathrm{~s}$. For the DGAT1 sequence (SNPs are located in position 10433 and 10434 of the sequence under GenBank acc. no. AJ318490) primers and labeled oligonucleotide probes were designed as 
follows: forward, 5'-CGC TTG CTC GTA GCT TTG G-3'; reverse, 5'-CGC GGT AGG TCA GGT TGT C-3'; FAM probe, 5'-TTG GCC GCC TTA C-3'; HEX probe, 5'-CGT TGG CCT TCT TAC-3'. In this case PCR conditions were: $95^{\circ} \mathrm{C}$ for $10 \mathrm{~min}$, followed by 15 cycles of $94^{\circ} \mathrm{C}$ for $20 \mathrm{~s}, 62^{\circ} \mathrm{C}$ for $30 \mathrm{~s}$ and $72{ }^{\circ} \mathrm{C}$ for $30 \mathrm{~s}$ and $35 \mathrm{cycles}$ of $94^{\circ} \mathrm{C}$ for $20 \mathrm{~s}, 38^{\circ} \mathrm{C}$ for $20 \mathrm{~s}$ and $72^{\circ} \mathrm{C}$ for $20 \mathrm{~s}$. TG polymorphism was detected using the PCR-RFLP method described by Barendse (1999). Digested PCR products were separated in 4\% Meta-Phor agarose gel (Rockland, ME, USA) in 1×TBE buffer and stained with ethidium bromide. As for each polymorphism about $5 \%$ of samples were genotyped in duplicate and repeatability was in all cases perfect. Milk production data of the genotyped cows were collected throughout three consecutive lactations and statistical analyses have been carried out to find association between genotypes and milk production traits.

\section{Statistical analysis}

Dataset was analysed with SPSS 15.0 for Windows (SPSS Inc., Chicago, IL, USA). Multivariate analysis of variance (general linear model, GLM) was applied to determine differences in milk production traits in case of all polymorphisms in all studied breeds. DGAT1, TG and leptin genotypes, birth year, number of lactations and calving season were included as fixed effects in mathematical models and 305-day-milk yield, 305-day-milk fat percentage and 305-daymilk protein percentage were considered as dependent variables.

So the formula of general linear model (GLM) was as follows in Hungarian Simmental breed:

$$
\begin{aligned}
y_{i j k l m n}= & \mu+\text { Lep }_{i}+T G_{j}+D G A T_{k}+\text { birth year }_{l}+\text { calving } \text { co }_{m}+\text { calving season }_{n}+ \\
& \text { Lepi } \times D G A T k+\text { Lep }_{i} \times T G_{j}+e_{i j k l m n}
\end{aligned}
$$

can be written in Holstein-Friesian breed as follows:

$$
\begin{aligned}
y_{i j k l m n}= & \mu+\text { Lep }_{i}+T G_{j}+D G A T_{k}+\text { birth year }_{l}+\text { calving } \text { co }_{m}+\text { calving season }_{n}+ \\
& \text { Lep }_{i} \times D G A T_{k}+D G A T_{k} \times T G_{j}+e_{i j k l m n}
\end{aligned}
$$

Finally GLM equation can be described in Jersey breed as follows:

$$
\begin{aligned}
y_{i j k l m n o}= & \mu+\text { Lep }_{i}+T G_{j}+D G A T_{k}+\text { birth year }_{1}+\text { calving } \text { no }_{m}+\text { calving season }_{n}+ \\
& \text { farm }_{o}+e_{i j k l m n}
\end{aligned}
$$

where $y$ is the phenotypic record of the studied traits (e.g. milk\%), $\mu$ is the general mean, Lep is the leptin hormone genotype (CC, TC, TT), TG refers to the $T G$ polymorphism (CC, TC, TT), DGAT represents the effect of DGAT1 genotypes (AA/AA, AA/GC, GC/GC), birth year means the year of birth, calving no stands for the number of completed lactations, calving season

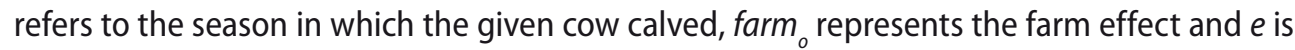
the residual error. Dominance effects were estimated as the deviation of mean values of the studied traits in heterozygotes from the mean of homozygotes, using the least square means. Additive effect was calculated as the half of the difference between the two homozygotes. Significant level of these factors was detected by the method of the least square difference (LSD). Variance in tables below represents the proportion of variation in the dependent variable explained by the regression model itself. 


\section{Results and discussion}

With regard to herd genetic structure analyses, differences between the observed and expected genotype frequency values of DGAT1 genotypes were significant only in the Jersey breed (Table 1). The calculated $\chi^{2}$ values for the leptin and TG genotypes indicated HardyWeinberg equilibrium in the population.

Table 1

Frequencies of DGAT1 genotypes in the studied breeds

\begin{tabular}{lcccccc}
\hline Breed & No. & $\mathrm{AA} / \mathrm{AA}^{*}$ & $\mathrm{AA} / \mathrm{GC}$ & $\mathrm{GC} / \mathrm{GC} * *$ & $\chi^{2}$ & $P$ \\
\hline Holstein-Friesian & 415 & $18(20)$ & $148(142)$ & $249(253)$ & 0.517 & 0.772 \\
$\%$ & 100 & $4.3(4.8)$ & $35.7(34.3)$ & $60.0(60.8)$ & & \\
Jersey & 340 & $233(217)$ & $86(109)$ & $21(14)$ & 9.533 & 0.009 \\
$\%$ & 100 & $68.5(64.0)$ & $25.3(32.0)$ & $6.2(4.0)$ & & \\
Hungarian Simmental & 481 & $8(5)$ & $79(86)$ & $394(390)$ & 2.411 & 0.300 \\
$\%$ & 100 & $1.7(1.0)$ & $16.4(18.0)$ & $81.9(81.0)$ & & \\
\hline
\end{tabular}

The expected values are presented in brackets $(\mathrm{df}=2),{ }^{*}$ coding for lysine, ${ }^{* *}$ coding for alanine

Referring to leptin genotypes, only the Jersey breed fit the Hardy-Weinberg equilibrium, in case of Holstein-Friesian and Hungarian Simmental breeds the calculated $\chi^{2}$ values did not indicate Hardy-Weinberg equilibrium in the population (Table 2).

Table 2

Frequencies of leptin genotypes in the studied breeds

\begin{tabular}{lcccccc}
\hline Breed & No. & CC & TC & TT & $\chi^{2}$ & $P$ \\
\hline Holstein-Friesian & 415 & $291(300)$ & $121(106)$ & $3(9)$ & 6.393 & 0.041 \\
$\%$ & 100 & $70.1(72.3)$ & $29.2(25.5)$ & $0.7(2.3)$ & & \\
Jersey & 341 & $255(258)$ & $84(77)$ & $2(6)$ & 3.338 & 0.188 \\
$\%$ & 100 & $74.8(75.7)$ & $24.6(22.6)$ & $0.6(1.7)$ & & \\
Hungarian Simmental & 485 & $257(273)$ & $212(182)$ & $16(30)$ & 12.416 & 0.002 \\
$\%$ & 100 & $53.0(56.3)$ & $43.7(37.5)$ & $3.3(6.3)$ & & \\
\hline
\end{tabular}

The expected values are presented in brackets $(\mathrm{df}=2)$.

Concerning TG genotypes there was a good agreement in all breeds between the observed and expected frequency values (Table 3). The calculated least square means (LSM) and standard errors for milk production traits of the three breeds included in this study are presented in Table 4, 5 and 6.

Table 3

Frequencies of $T G$ genotypes in the studied breeds

\begin{tabular}{lcccccc}
\hline Breed & No. & CC & TC & TT & $\chi^{2}$ & $P$ \\
\hline Holstein-Friesian & 415 & $309(310)$ & $100(97)$ & $6(8)$ & 0.596 & 0.742 \\
$\%$ & 100 & $74.5(74.8)$ & $24.1(23.4)$ & $1.4(1.8)$ & & \\
Jersey & 283 & $170(172)$ & $99(97)$ & $14(14)$ & 0.064 & 0.968 \\
$\%$ & 100 & $60.1(60.8)$ & $35(34.3)$ & $4.9(4.9)$ & & \\
Hungarian Simmental & & $234(233)$ & $171(173)$ & $33(32)$ & 0.059 & 0.971 \\
$\%$ & 100 & $53.5(53.3)$ & $39.0(39.4)$ & $7.5(7.3)$ & & \\
\hline
\end{tabular}

The expected values are presented in brackets $(\mathrm{df}=2)$. 
Table 4

Least square means (LSM) and standard errors, variance, additive effect and dominance for 305-day milk yield, milk fat percent and milk protein percent in Holstein-Friesian cows

\begin{tabular}{llccc}
\hline Loci & Genotype & & LSM \pm SE \\
& & 305-day milk yield, kg & 305-day milk fat, $\%$ & 305-day milk protein, \% \\
\hline DGAT1 & AA/AA & $8247.1 \pm 563.3^{\mathrm{a}}$ & $4.344 \pm 0.126^{\mathrm{a}}$ & $3.410 \pm 0.054^{\mathrm{a}}$ \\
& AAGC & $9079.1 \pm 385.0^{\mathrm{a}}$ & $3.782 \pm 0.086^{\mathrm{b}}$ & $3.275 \pm 0.037^{\mathrm{b}}$ \\
& GC/GC & $9532.7 \pm 335.8^{\mathrm{b}}$ & $3.725 \pm 0.075^{\mathrm{c}}$ & $3.229 \pm 0.032^{\mathrm{c}}$ \\
& Variance, $\%$ & 2.9 & 11.5 & 4.0 \\
& Additive effect & $642.8^{*}$ & $0.310^{*}$ & $0.091^{*}$ \\
& Dominance & $189.2^{*}$ & $-0.253^{*}$ & $-0.045^{*}$ \\
Leptin & $9213.9 \pm 182.9$ & $3.821 \pm 0.041$ & $3.301 \pm 0.018^{\mathrm{a}}$ \\
& CC & $9262.9 \pm 283.2$ & $3.946 \pm 0.063$ & $3.258 \pm 0.027^{\mathrm{b}}$ \\
& TC & $8783.8 \pm 663.3$ & $3.845 \pm 0.148$ & $3.287 \pm 0.064 \mathrm{a}^{\mathrm{b}}$ \\
& TT & 0 & 0 & 0.9 \\
& Variance, $\%$ & 215.1 & 0.012 & 0.007 \\
& Additive effect & 264.1 & 0.113 & $-0.036^{*}$ \\
& Dominance & $9179.7 \pm 226.1^{\mathrm{a}}$ & $3.878 \pm 0.050$ & $3.269 \pm 0.022$ \\
& CC & $8964.7 \pm 314.1^{\mathrm{b}}$ & $3.857 \pm 0.070$ & $3.297 \pm 0.030$ \\
& TC & $9367.1 \pm 556.8^{\mathrm{a}}$ & $3.906 \pm 0.124$ & $3.275 \pm 0.054$ \\
& TT & 0.1 & 0 & 0 \\
& Variance, $\%$ & 93.7 & 0.014 & 0.003 \\
& Additive effect & $-308.7^{*}$ & -0.035 & +0.025 \\
\hline
\end{tabular}

Variance: percentage of variance due to the studied loci in the total phenotypic variance, a,b,c Different letters indicate significant difference between genotypes, * confidence level of the predicted factors $(P<0.05)$

Table 5

Least square means (LSM) and standard errors, variance, additive effect and dominance for 305-day milk yield, milk fat percent and milk protein percent in Jersey cows

\begin{tabular}{llccc}
\hline Loci & Genotype & & LSM \pm SE & \\
& & 305-day milk yield, kg & 305-day milk fat, $\%$ & 305-day milk protein, \% \\
\hline DGAT1 & AA/AA & $4676.6 \pm 221.2^{\mathrm{a}}$ & $5.383 \pm 0.168^{\mathrm{a}}$ & $3.958 \pm 0.065^{\mathrm{a}}$ \\
& AAGC & $4848.3 \pm 230.9^{\mathrm{b}}$ & $5.047 \pm 0.176^{\mathrm{b}}$ & $3.844 \pm 0.068^{\mathrm{b}}$ \\
& GCGC & $4853.2 \pm 243.7^{\mathrm{a}, \mathrm{b}}$ & $5.054 \pm 0.186^{\mathrm{c}}$ & $3.785 \pm 0.071^{\mathrm{b}}$ \\
& Variance, \% & 0.1 & 8.2 & 4.3 \\
& Additive effect & 88.3 & $0.165^{*}$ & $0.087^{*}$ \\
& Dominance & $83.4^{*}$ & $-0.172^{*}$ & $-0.028^{*}$ \\
Leptin & CC & $5904.6 \pm 181.8$ & $5.040 \pm 0.138$ & $3.842 \pm 0.053$ \\
& TC & $4806.4 \pm 191.7$ & $5.113 \pm 0.146$ & $3.851 \pm 0.056$ \\
& TT & $4667.1 \pm 425.8$ & $5.031 \pm 0.324$ & $3.894 \pm 0.124$ \\
& Variance, \% & 0 & 0 & 0 \\
& Additive effect & 118.75 & 0.005 & 0.026 \\
& Dominance & 20.55 & 0.078 & -0.017 \\
& CC & $4858.9 \pm 216.6^{\mathrm{a}}$ & $4.987 \pm 0.165^{\mathrm{a}}$ & $3.850 \pm 0.063$ \\
& TC & $4829.3 \pm 216.8 \mathrm{a}^{\mathrm{b}}$ & $5.078 \pm 0.165^{\mathrm{b}}$ & $3.863 \pm 0.063$ \\
& TT & $4689.9 \pm 238.7^{\mathrm{b}}$ & $5.118 \pm 0.182^{\mathrm{a}, \mathrm{b}}$ & $3.875 \pm 0.070$ \\
& Variance, ${ }^{\#}$ & 1.0 & 0.7 & 0 \\
& Additive effect & $84.5^{*}$ & 0.066 & 0.013 \\
& Dominance & 54.9 & $0.026^{*}$ & 0.0005 \\
\hline
\end{tabular}

a,bdifferent letters indicate significant difference between genotypes, ${ }^{*}$ confidence level of the predicted factors $(P<0.05)$, "percentage of variance due to the studied loci in the total phenotypic variance 
In all breeds DGAT1 GC/GC cows had the highest and AA/AA cows the lowest 305-day milk yield values. Contrasting the AA/AA genotype vs. GC/GC, the difference proved to be significant $(P<0.05)$. There was a negative correlation between milk yield and milk fat percentage, so in case of 305-day milk fat percent a decreasing tendency could be observed from genotype $A A$ / AA to GC/GC. Differences between genotypes were significant $(P<0.05)$. In respect of milk fat content, similar results were obtained by Winter et al. (2002) in Holstein-Friesian, Simmental and Braunvieh breeds, by Strzałkowska et al. (2005) in Polish Black-and-White (Friesian) cattle, and by Schennink et al. (2007) in Dutch Holstein-Friesian cows. Concerning 305-day milk fat percentage, estimated variances within dependent variables caused by DGAT1 genotypes in the Holstein-Friesian, Jersey and Hungarian Simmental breeds were 11.5, 8.2 and 9.2\%, respectively. Considering 305-day milk protein percent, AA/AA animals showed significantly higher values $(P<0.05)$ than other genotypes. Effects of the DGAT1 K232A polymorphism on milk yield, fat and protein percentage are consistent with previous studies made by Grisart et al. (2002) and Spelman et al. (2002).

Table 6

Least square means (LSM) and standard errors, variance, additive effect and dominance for 305-day milk yield, milk fat percent and milk protein percent in Hungarian Simmental cows

\begin{tabular}{|c|c|c|c|c|}
\hline \multirow[t]{2}{*}{ Loci } & \multirow[t]{2}{*}{ Genotype } & \multicolumn{3}{|c|}{$\mathrm{LSM} \pm \mathrm{SE}$} \\
\hline & & 305-day milk yield, kg & 305-day milk fat, $\%$ & 305 -day milk protein, $\%$ \\
\hline \multirow[t]{6}{*}{ DGAT1 } & $\mathrm{AA} / \mathrm{AA}$ & $4417.8 \pm 315.3^{a}$ & $4.746 \pm 0.102^{\mathrm{a}}$ & $3.811 \pm 0.046^{\mathrm{a}}$ \\
\hline & AAGC & $4788.4 \pm 194.6^{b}$ & $4.359 \pm 0.063^{b}$ & $3.661 \pm 0.028^{b}$ \\
\hline & GC/GC & $5109.1 \pm 122.2^{b}$ & $4.110 \pm 0.040^{c}$ & $3.554 \pm 0.018^{c}$ \\
\hline & Variance, $\% \#$ & 0.4 & 9.2 & 6.0 \\
\hline & Additive effect & $345.7^{*}$ & $0.318^{*}$ & $0.129 *$ \\
\hline & Dominance & $25.0^{*}$ & $-0.069^{*}$ & $-0.022^{*}$ \\
\hline \multirow[t]{6}{*}{ Leptin } & CC & $4685.1 \pm 170.7$ & $4.362 \pm 0.055^{\mathrm{a}}$ & $3.694 \pm 0.025^{\mathrm{a}}$ \\
\hline & TC & $5164.2 \pm 191.0$ & $4.339 \pm 0.062^{b}$ & $3.607 \pm 0.028^{b}$ \\
\hline & TT & $4490.2 \pm 340.1$ & $4.398 \pm 0.099^{c}$ & $3.681 \pm 0.044^{c}$ \\
\hline & Variance, $\% \#$ & 0 & 0.1 & 0.3 \\
\hline & Additive effect & 97.5 & $0.018^{*}$ & $0.007^{*}$ \\
\hline & Dominance & 576.6 & $-0.041^{*}$ & $-0.081^{*}$ \\
\hline \multirow[t]{6}{*}{$T G$} & CC & $5001.4 \pm 141.4^{\mathrm{a}}$ & $4.283 \pm 0.046$ & $3.628 \pm 0.020^{\mathrm{a}}$ \\
\hline & TC & $4963.2 \pm 148.9^{b}$ & $4.330 \pm 0.048$ & $3.643 \pm 0.022^{b}$ \\
\hline & TT & $4483.6 \pm 223.0^{b}$ & $4.474 \pm 0.072$ & $3.704 \pm 0.032^{b}$ \\
\hline & Variance, $\%^{\#}$ & 1.0 & 0 & 1.1 \\
\hline & Additive effect & $255.2^{*}$ & 0.096 & $0.038^{*}$ \\
\hline & Dominance & $217.0^{*}$ & -0.049 & $-0.023^{*}$ \\
\hline
\end{tabular}

a,b,cDifferent letters indicate significant difference between genotypes, ${ }^{*}$ confidence level of the predicted factors $(P<0.05)$, "percentage of variance due to the studied loci in the total phenotypic variance

As for leptin locus there was no demonstrable effect of the genotype on milk yield. Differences of means could not be proved to be significant in Holstein-Friesian and Jersey breeds, due to the small number of TT cows and the large standard error. Concerning Hungarian Simmental breed, leptin CC animals showed significantly higher 305-day milk protein percent values $(P<0.05)$ than other genotypes. In this breed leptin TT cows realised the highest milk fat percentage values; the difference between genotypes was significant $(P<0.05)$. Some previous studies have focused on associations between polymorphisms in 
the coding region of the leptin gene and milk production traits (Liefers et al. 2002, Buchanan et al. 2003). However there are no former results concerning the effect of promoter region UASMS2 polymorphism (present study) on milk production traits.

Referring to TG locus, TT cows produced in all breeds the highest 305-day milk fat percent values; in case of Jersey and Hungarian Simmental breeds differences between CC and TT genotypes were significant $(P<0.05)$. Former analysis of 29 Holstein sire families showed no significant association between TG variants and milk production traits (Khatib et al. 2007).

Our previous research in Angus cattle (Anton et al. 2011) revealed that leptin and thyroglobulin TT animals could be associated with the highest intramuscular fat content values, similarly to the milk fat content in the current study.

The present study was carried out to test the possible association of three specific polymorphisms with milk production traits. An eventual marker assisted selection (MAS) approach - such as selecting for AA/AA genotypes at the DGAT1 locus - might be performed, if higher milk yield is preferred. In this case, simultaneous selection for leptin and thyroglobulin TT genotypes could increase milk fat and protein percentage as well. However, from public health point of view Schennink et al. (2007) recommend to increase alanin variant (GC/GC) of DGAT1 in the population by selective breeding (because of its association with more unsaturated milk-fat), reducing in this way saturated fatty acid intake of humans.

\section{Acknowledgements}

This project was supported by the Hungarian Scientific Research Fund and National Office for Research and Technology (Project 78174). Authors thank the owners of the herds for their help in collecting blood samples and milk production data.

\section{References}

Anton I, Kovács K, Holló G, Farkas V, Lehel L, Hajda Z, Zsolnai A (2011) Effect of leptin, DGAT1 and TG gene polymorphisms on the intramuscular fat of Angus cattle in Hungary. Livest Sci 135, 300-303

Barendse WJ (1999) Assessing lipid metabolism. Patent. International publication Number: WO 99/23248, World International Property Organization

Bennewitz J, Reinsch N, Paul S, Looft C, Kaupe B, Weimann C, Erhardt G, Thaller G, Kühn C, Schwerin M, Thomsen $\mathrm{H}$, Reinhardt F, Reents R, Kalm E (2004) The DGAT1 K232A Mutation is not solely responsible for the Milk Production Quantitative Trait Locus on the Bovine Chromosome 14. J Dairy Sci 87, 431-442

Buchanan FC, Van Kessel AG, Waldner C, Christensen DA, Laarveld B, Schmutz SM (2003) Hot Topic: An association between a leptin single nucleotide polymorphism and milk and protein yield. J Dairy Sci 86, 3164-3166

Coppieters W, Riquet J, Arranz J, Berzi P, Cambisano N, Grisart B, Karim L, Marcq F, Moreau L, Nezer C, Simon P, Vanmanshoven P, Wagenaar D, Georges M (1998) A QTL with major effect on milk yield and composition maps to the bovine chromosome 14. Mamm Genome 9, 540-544

Gautier M, Capitan A, Fritz S, Eggen A, Boichard D, Druet T (2007) Characterization of the DGAT1 K232A and Variable Number of Tandem Repeat polymorphisms in French Dairy Cattle. J Dairy Sci 90, 2980-2988

Grisart B, Coppieters W, Farnir F, Karim L, Ford C, Berzi P, Cambisano N, Mni M, Reid S, Simon P, Spelman R, Georges M, Snell R (2002) Positional Candidate Cloning of a QTL in Dairy Cattle: Identification of a Missense Mutation in the Bovine DGAT1 Gene with Major Effect on Milk Yield and Composition. Genome Res 12, 222-231 
Ji S, Willis GM, Scott RR, Spurlock ME (1998) Partial cloning and expression of the bovine leptin gene. Anim Biotechnol 9, 1-4

Khatib H, Zaitoun I, Chang YM, Maltecca C, Boettcher P (2007) Evaluation of association between polymorphism within the thyroglobulin gene and milk production traits in dairy cattle. J Anim Breed Genet 124, 26-28

Khatkar MS, Thomson PC, Tammen I, Raadsma HW (2004) Quantitative trait loci mapping in dairy cattle: review and meta-analysis. Genet Sel Evol 36, 163-190

Kühn C, Thaller G, Winter A, Bininda-Emonds ORP, Kaupe B, Erhardt G, Bennewitz J, Schwerin M, Fries R (2004) Evidence for Multiple Alleles at the DGAT1 Locus Better Explains a Quantitative Trait Locus With Major Effect on Milk Fat Content in Cattle. Genetics 167, 1873-1881

Liefers SC, te Pas MFW, Veerkamp RF, van der Lende T (2002) Associations between leptin gene polymorphisms and production, live weight, energy balance, feed intake, and fertility in Holstein heifers. J Dairy Sci 85, 1633-1638

Moore S, LI C, Basarab J, Snelling W, Kneeland J, Murdoch B, Hansen C, Benkel B (2003) Fine mapping of quantitative trait loci and assessment of positional candidate genes for backfat on bovine chromosome 14 in a commercial line of Bos Taurus. J Anim Sci 81, 1919-1925

Nkrumah JD, Li C, Yu J, Hansen C, Keisler DH, Moore SS (2005) Polymorphisms in the bovine leptin promoter associated with serum leptin concentration, growth, feed intake, feeding behavior, and measures of carcass merit. J Anim Sci 83, 20-28

Sanders K, Bennewitz J, Reinsch N, Thaller G, Prinzenberg EM, Kühn C, Kalm E (2006) Characterization of the DGAT1 Mutations and the CSN1S1 Promoter in the German Angeln Dairy Cattle Population. J Dairy Sci 89, 3164-3174

Schennink A, Stoop WM, Visker MHPW, Heck JML, Bovenhuis H, van der Poel JJ, van Valenberg HJF, van Arendonk JAM (2007) DGAT1 underlies large genetic variation in milk-fat composition of dairy cows. Anim Genetics 38, 467-473

Spelman RJ, Ford CA, McElhinney P, Gregory GC, Snell RG (2002) Characterization of the DGAT1 gene in the New Zealand dairy population. J Anim Sci 85, 3514-3517

Stone RT, Kappes SM, Beattie CW (1996) The bovine homolog of the obese gene maps to chromosome 4. Mamm Genome 7, 399-400

Strzałkowska N, Siadkowska E, Słoniewski K, Krzyżewski J, Zwierzchowski L (2005) Effect of the DGAT1 gene polymorphism on milk production traits in Black-and-White (Friesian) cows. Anim Sci Pap Rep 23, 189-197

Thaller G, Krämer W, Winter A, Kaupe B, Erhardt G, Fries R (2003) Effects of DGAT1 variants on milk production traits in German cattle breeds. J Anim Sci 81, 1911-1918

Winter A, Krämer W, Werner FA, Kollers S, Kata S, Durstewitz G, Buitkamp J, Womack JE, Thaller G, Fries R (2002) Association of a lysine-232/alanine polymorphism in a bovine gene encoding acyl-CoA: diacylglycerol acyltransferase (DGAT1) with variation at a quantitative trait locus for milk fat content. Proc Natl Acad Sci USA 99, 9300-9305

Zhang Y, Proenca R, Maffei M, Barone M, Leopold L, Friedman JM (1994) Positional cloning of the mouse obese gene and its human homologue. Nature 372, 425-432

Zsolnai A, Anton I, Kühn C, Fésüs L (2003) Detection of single-nucleotide polymorphisms coding for three ovine prion protein variants by primer extension assay and capillary electrophoresis. Electrophoresis $24,634-638$

Received 19 October 2011, accepted 10 January 2012.

Corresponding author:

Klaus-Peter Brüssow

email: bruessow@fbn-dummerstorf.de

Leibniz Institute for Farm Animal Biology (FBN), Wilhelm-Stahl-Allee 2, Dummerstorf 18196, Germany 